\title{
The use of sensory perception of blind and visually impaired masseurs for the purpose of early-stage breast cancer screening by palpation (the "Breast-POL" project)
}

\author{
Lidia Rakow ${ }^{1,2}$, Zbigniew Lewandowski², Ewa Romejko-Wolniewicz ${ }^{3}$, \\ Małgorzata Pękala ${ }^{4}$, Józef Piotr Knap ${ }^{2}$
}

\begin{abstract}
Introduction. Methodological assumptions as well as the initial stage of the execution of the project entitled "Breast$-\mathrm{POL}^{\prime \prime}$ - the use of sensory perception of blind and visually impaired masseurs for the purpose of breast cancer screening by palpation were presented.

Materials and methods. A list of incentives to conduct this methodologically adequate study includes: 1 . Encouraging and widely disseminated German reports (these reports, however, were of high generality and they did not provide the adequate methodology); 2 . Theoretical data on the hypercompensation of other senses than vision in the blind; 3. Preliminary information on the involvement of the blind in breast cancer screening by palpation in developing countries.

Results. Compared to people with normal vision, a statistically significant higher sensitivity (63.0 vs $47.5 \%)$ and lower specificity ( 89.6 vs $93.7 \%$ ) in the detection of pathological lesions, using a phantom, was reported in the blind. Conclusion. Our study confirms that the detection of pathological breast lesions by the blind is highly effective, however, the ability to exclude such lesions was not of clinical significance.
\end{abstract}

NOWOTWORY J Oncol 2016; 66, 6: 457-462

Key words: breast cancer, screening, prevention, palpation, blind people

\section{Introduction}

Screening, which is a widely used method to detect early-stage breast cancer, plays a fundamental role in the prognosis of this cancer, which is the most prevalent malignant tumour in women in Poland [1, 2]. Introduction of this testing fulfils the WHO criteria for primary and secondary prevention. A number of clinical and epidemiological studies carried out worldwide (including Poland) confirmed the utility of physical examinations (palpation) of the breast for the purpose of the early detection of cancer in women, consequently, leading to an improvement of its prognosis [3-9].

Probably, the idea to screen the early stages of breast cancer by the blind was first introduced by Prof. Maria Heng- stberger, MD, a gynaecologist in Vienna (born in 1941), at the beginning of the 1980s. Such a concept emerged while she was working in Ethiopia where many women were dying due to the lack of early diagnosis of this cancer. Furthermore, improvement of diagnoses by employing the abilities of the blind came about as a result of the high prevalence of blindness in Ethiopia which was due to the lack of adequate therapies for trachoma and onchocerciasis. The idea of Prof. Hengstberger was expressed in 2003, using the following words: "Die Idee, den Tastsinn blinder Menschen im Bereich der Brustkrebsdiagnose gezielt einzusetzen, hatte Frau Maria Hengstberger vor etwas mehr als 20 Jahren". However, the results of these examinations are not available. There is

${ }^{1}$ Department of Health Promotion and Postgraduate Education of the National Institute of Public Health — National Institute of Hygiene, Warszawa, Poland

${ }^{2}$ Department of Epidemiology of the Medical University of Warsaw, Warszawa, Poland

${ }^{3} 2^{\text {nd }}$ Department of Obstetrics and Gynaecology of the Medical University of Warsaw, Warszawa, Poland

${ }^{4}$ Duchess Anna Mazowiecka Public Teaching Hospital, Warszawa, Poland 
a similarity between the aforementioned idea and the projects presented by Dr Frank Hoffmann (born in 1959), a gynaecologist in Duisburg, which were disseminated in the media. They consisted of the use of the abilities of trained blind and visually impaired women to diagnose breast cancer in women by palpation. No published data are available. From e-mail materials, published since 2008, which are of high generality [e.g. 10], appears that a total of 21 blind people were involved in the process of breast examination, using palpation techniques. These people were trained for this purpose over a period of 9 months. The results of these examinations, however, are ambiguous. It was only specified that out of 450 women tested, 56 were diagnosed with early-stage breast cancer (the diagnostic predominance of the blind was not provided).

Due to the lack of data for both studies, it may be presumed that the criteria of scientific correctness were not met for these encouraging findings as was stated by Hoffmann.

Studies from Brazil [11, 12], Saudi Arabia, Venezuela and Egypt [5] present a different aspect of this phenomenon, i.e. a lack of knowledge of the blind girls and women with regard to breast self-examination (BSE). Taking into account the inability to identify visually alarming breast lesions, they cannot detect early-stage changes which have a of better prognosis.

Having considered these intriguing theoretical assumptions and the necessity of improving early screening of breast cancer in women as an important aspect of public health in Poland, an effort was undertaken to discuss this subject from a national perspective, using precise methodological criteria. The present preliminary report discusses the efforts undertaken to execute such assumption as well as the methodological difficulties that appeared at the early stage of its execution and the corrective measures applied.

\section{Theoretical justification of this study The value of physical examinations of the breast in the case of breast cancer screening}

Undoubtedly, the value of the examination and palpation of the breast (CBE - clinical breast examination) and its neighbouring regions by both physicians and patients (self-examination, BSE - breast self-examination) has been proven for decades worldwide, including Poland [e.g. 8, 13]. Furthermore, these methods meet the WHO criteria for screening, including simplicity, reliability and low costs of CBE and BSE. These examinations should be accompanied by mammography which is considered to be the most reliable method of early detection of breast cancer. It is assumed that the sensitivity of CBE is about $60 \%$ of that for mammography [8], however, CBE may detect breast cancers which cannot be identified by radiological techniques [7].

\section{Potential diagnostic predominance of physical examinations conducted by the blind}

The justification of involving blind women for the purpose of diagnosis by palpation was not sufficiently provided by Maria Hengstberger nor Frank Hoffmann. Generally, it was assumed that the sense of touch, which is heightened in the blind as a result of compensation mechanisms, will allow, after training to enhance their abilities, for more regular detection of breast nodules - including smaller lesions. According to Hoffmann: "There are still numerous diagnostics fields and application areas where blind people can apply their tactile senses meaningfully. Especially in areas where an instrument-based diagnostic is no matter of course". He assumed that palpation conducted by physicians allows for the detection of nodules measuring $1-2 \mathrm{~cm}$ in diameter while the blind are capable of identifying lesions of size equal to $6-8 \mathrm{~mm}$. He also gave an example of the blind diagnostician who detected a cancer measuring $2 \mathrm{~mm}$ in a left breast. He propounded the general concept of "discovering hands".

What is the value of these theoretical assumptions (here we pay no attention to the possibility of their use in diagnosis)?

A total loss of vision (blindness) was precisely defined in the International Classification of Diseases, 10th Revision (ICD-10). It originates from the WHO definition as of 1972. It is defined as a severe psychophysical disability which affects humans worldwide as we live in a world mainly based on vision [14]. Blindness (severe visual impairment) triggers a range of compensation mechanisms which concern all other senses and mechanisms of synthesis and associations. This processes were discussed in a number of publications. Here we present some classic examples [15-19]. Compensation mechanisms are possible thanks to the plasticity of the brain [14]. This phenomenon was first described and introduced to the literature (plasticity of the brain, neuroplasticity) in 1948 by Jerzy Konorski (1903-1973), the great Polish neurophysiologist. He correctly postulated (today it is unequivocal) that morphological, stable synaptic changes are the basis of plasticity. Konorski wrote that: "The first property, by virtue of which the nerve cells react to the incoming impulses with a certain cycle of changes, we call excitability, and the changes arising in centres because of this property we shall call changes due to excitability. The second property, by virtue of which certain permanent functional transformations arise in particular systems of neurons as the result of appropriate stimuli or their combinations, we shall call plasticity, and the corresponding changes plastic changes" [translation from English by B. Żernicki, 20]. The compensation of visual deprivation was confirmed by the school of Konarski in a study carried out in cats for 20 years $[19,20]$ as well as by other 
centres worldwide. Having considered the compensation of an impaired or damaged visual analyser in humans, Ella Striem-Amit studied the phenomenon of brain plasticity recently [14].

There is also an opinion (cited cautiously by e.g. Murray and Wallace) [17] that the sense of touch is not - or rather - is partly subject to compensation sensitisation in the blind. The complexity of the sense of touch [21] and the mechanisms of "compensation plasticity" of the brain [20] undermine such a stringent approach. Furthermore, the sense of touch is commonly used by the blind who make use of Braille. Studies carried out in the last decade with regard to the compensation plasticity of the sense of touch in the blind [22] or the enhancement of vibrotactile perception in people with congenital blindness [23] resolve all doubts that were mentioned earlier. Having considered similar assumptions, the study consisted of the screening of eyeballs by palpation was designed in Iran to search for people with elevated intra-ocular pressure - different forms of glaucoma [24]. Taking this into account, as well as the lack of information on the quality of the sense of touch in the blind, i.e. its higher sensitivity, we decided to train certified blind masseurs by two gynaecologists, who are well-experienced in breast examinations, together with phantom exercises. Furthermore, the results obtained were considered to be the baseline of actual possibilities of the sense of touch in people with blindness or impaired vision - prior to the implementation of a proper study in a group of patients.

\section{Our research — preliminary presentation of assumptions and methodology}

The arguments which were presented above induced us to undertake our own interdisciplinary research. Contrary to the assumptions of Hengstberger and Hoffmann, our research was based on precise methodological criteria. Such designed research was approved by the Ethics Committee of the National Institute of Public Health - the National Institute of Hygiene and the Polish Association of the Blind. A scientific project called "Innovative improvement of breast cancer screening: an education and training programme for people with impaired vision (acronym Breast-POL)" was given a green light from the National Centre for Research and Development in Warsaw (the project was marked as "Project IS-2/235/NCDR/2015" and divided into successive stages). Stage I is called "Assessment of sensory predispositions in mammography diagnosticians" and is discussed in the present paper.

From the aforesaid considerations concerning the lack of (or rather small) compensation of the sense of touch in the blind, the necessity of involving the certified masseurs and/or physical therapists for the purpose of this research was assumed. Contrary to the material of Hoffmann, where
Table I. Schemes in control and study group

\begin{tabular}{lcccc}
\hline Group & \multicolumn{3}{c}{ Scheme } & Total \\
\cline { 2 - 4 } & $\mathbf{1}$ & $\mathbf{2}$ & $\mathbf{3}$ & \\
\hline $\begin{array}{l}\text { Control group } \\
\text { (normal vision) }\end{array}$ & 6 & 10 & 4 & $\mathrm{n}=20$ \\
$\begin{array}{l}\text { Study group } \\
\text { (blindness/impaired } \\
\text { vision) }\end{array}$ & 6 & 9 & 3 & $\mathrm{n}=18$ \\
\hline
\end{tabular}

the blind, untrained people were engaged. Following the training, the verification, including their utility, was assessed using phantom, and then estimated.

A total of 9 masseurs with blindness or severe impairment of vision (low vision) were qualified for the examinations of breasts by palpation, including 4 men ( 1 with blindness) and 5 women ( 4 with blindness). The control group was composed of 10 students in their sixth year of medicine. Following the training, a theoretical and practical exam was organised. Its results are presented in Table I.

The following breast phantom was used - "Advanced Breast Examination Trainer" (producer: Limbs \& Things Ltd.) with a set of 5 pathological breast lesions and 3 axillary lymph nodes. Phantom allowed for the placement of lesions suggesting cyst, fibroadenoma and the following models of cancers according to presented schemes (Fig. 1):

- models of isolated cancers of spherical shapes measuring $5 \mathrm{~mm}$ in diameter;

- models of cancers of irregular shapes measuring $1.5 \mathrm{~cm}$ in diameter (later referred to as cancer of intermediate dimensions);

- models of cancers of irregular shapes measuring $3 \mathrm{~cm}$ in diameter (later referred to as cancer of large dimensions).

A total of 6 schemes of placing the models of pathological lesions were prepared, i.e. 3 in each breast: 4 and 2 situated medially and peripherally, respectively. A total of 5 models of different sizes and shapes were applied:

- 2 large cancers of irregular shapes;

- 10 cancers of irregular shapes and intermediate dimensions,

- 4 isolated cancers of small dimensions;

- 3 fibroadenomas;

-2 cysts.

All models were placed with accuracy to 30 degrees. They were noted in a clockwise direction, beginning from 12.00 .

\section{Preparation of diagnostic stand and the method of examinations}

1. The phantom was placed in a manner that each person was situated in such a position towards the phantom that it corresponded to the position at the right site of the lying patient.

2. People walked into the examination separately. After leaving, they could not communicate with one another. 


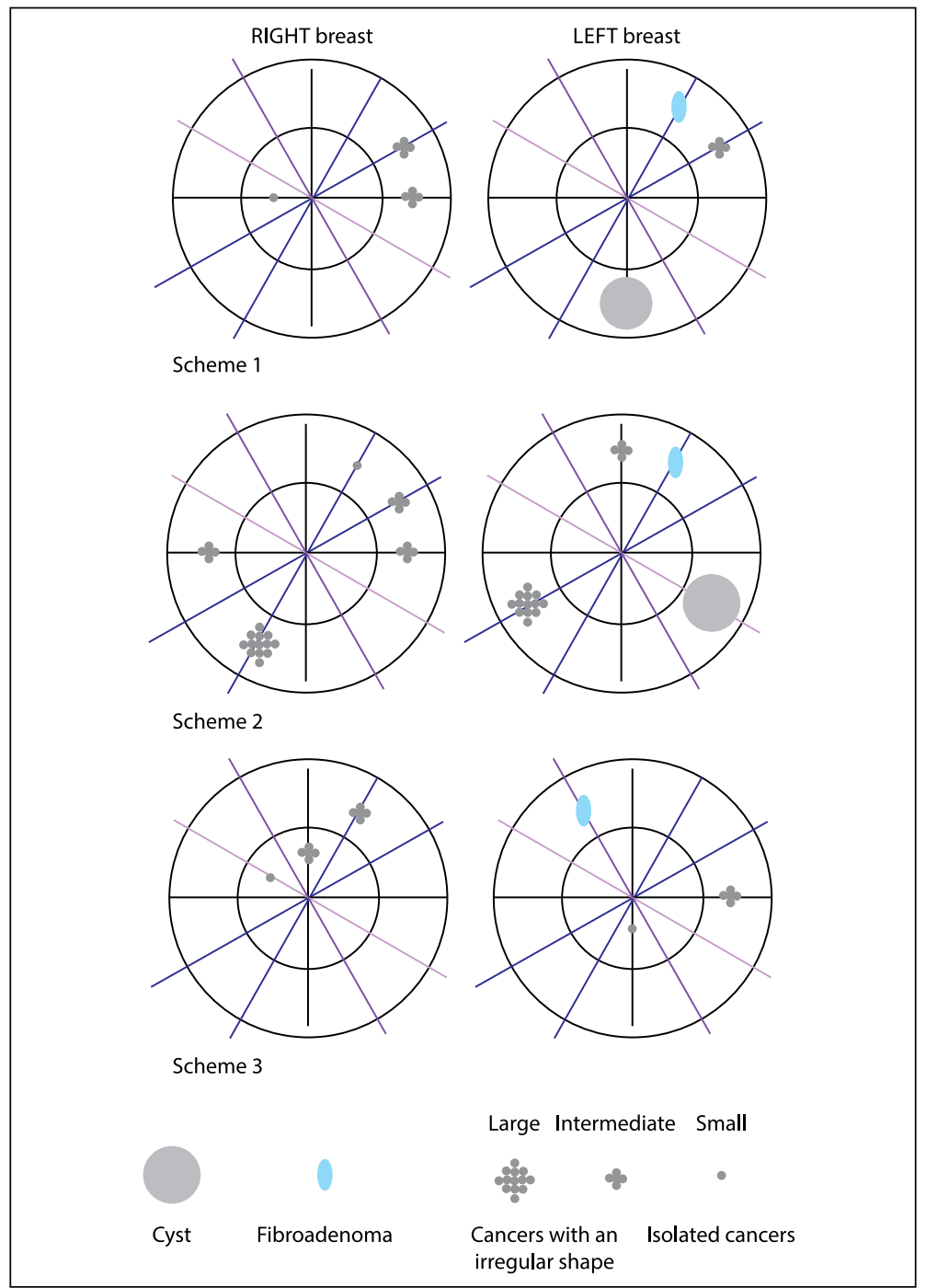

Figure 1. Schemes of imitations

3. Each of the examined people reported on the location of the lesion identified with accuracy to one hour - an incorrect location was not verified by the recorder.

4. Two trained people looked after the correct placement of the phantom and its preparation and adequate communication between the recorder and the person examined.

5. All results were recorded on the schemes enclosed together with a univocal number assigned to each person examined (Fig. 1).

Tests of sensitivity and specificity were carried out in 24 locations on each model of breast - each of the imitations was divided into internal (medial) and external (peripheral) parts, into 12 equal sections measuring 30 degrees. Each people was to examine 48 locations ( 24 in each breast model). Fisher's exact test was applied in statistical analysis. Methodology of the assessment of sensitivity and specificity was based on the monography by $\mathrm{G}$. van de Belle et al. (van de Belle et al., 2004) [25]. Data were collected using the
FSEDIT procedure, the SAS System (SAS Institute, 2012) [26] - licence of the Medical University of Warsaw. The FREQ procedure was adopted for the purpose of calculations.

In the second part of this experiment, the aforementioned people examined a total of 120 patients with different breast nodular lesions whose aetiology was verified histopathologically.

\section{Preliminary results}

It was stated that the people from the study group (the blind) had a substantially higher sensitivity (detection of the model of pathological lesion) compared to people with normal vision (control group). Sensitivity was assessed at 63.0 and $47.5 \%$, respectively ( $p<0.024 ;$ Tab. I). Higher sensitivity was also observed in the group of the blind with regard to the peripheral part of the breast - the sensitivity for the group of people with normal vision and blindness was: 67.7 and $52.0 \%$, respectively $(p<0.029)$. Sensitivity for medial parts of the breasts was also higher in the study group 
Table II. Comparison between the blind (B) and people with normal vision (V) with regard to the sensitivity and specificity of the diagnosis of any lesions

\begin{tabular}{|c|c|c|c|c|c|c|c|c|c|c|}
\hline \multirow{2}{*}{$\begin{array}{l}\text { Imitation type } \\
\text { and location } \\
\text { Any lesion }\end{array}$} & \multicolumn{4}{|c|}{ Sensitivity } & \multirow[t]{2}{*}{$p$} & \multicolumn{4}{|c|}{ Specificity } & \multirow[t]{2}{*}{$p$} \\
\hline & & & & & & & & & & \\
\hline Total & $\mathrm{n}=108$ & $63.0 \%$ & $\mathrm{n}=120$ & $47.5 \%$ & 0.024 & $n=756$ & $89.6 \%$ & $\mathrm{n}=840$ & $93.7 \%$ & 0.004 \\
\hline Peripherally & $n=93$ & $67.7 \%$ & $\mathrm{n}=102$ & $52.0 \%$ & 0.029 & $\mathrm{n}=339$ & $78.8 \%$ & $\mathrm{n}=378$ & $87.8 \%$ & 0.001 \\
\hline Medially & $\mathrm{n}=15$ & $33.3 \%$ & $\mathrm{n}=18$ & $22.2 \%$ & 0.697 & $\mathrm{n}=417$ & $98.3 \%$ & $\mathrm{n}=462$ & $98.5 \%$ & 0.999 \\
\hline
\end{tabular}

Table III. Comparison between the blind and people with normal vision with regard to the sensitivity and specificity of the diagnosis of isolated cancers of small dimensions

\begin{tabular}{|c|c|c|c|c|c|c|c|c|c|c|}
\hline \multirow{3}{*}{$\begin{array}{l}\text { Imitation type } \\
\text { and location }\end{array}$} & \multicolumn{4}{|c|}{ Sensitivity } & \multirow{3}{*}{$\begin{array}{c}p \\
0.138\end{array}$} & \multicolumn{4}{|c|}{ Specificity } & \multirow{3}{*}{$\begin{array}{c}p \\
0.002\end{array}$} \\
\hline & \multicolumn{2}{|c|}{ B } & \multicolumn{2}{|c|}{ v } & & \multicolumn{2}{|c|}{ B } & \multicolumn{2}{|c|}{ v } & \\
\hline & $n=21$ & $52.4 \%$ & $n=24$ & $29.2 \%$ & & $n=843$ & $83.9 \%$ & $n=939$ & $89.0 \%$ & \\
\hline Peripherally & $\mathrm{n}=9$ & $77.8 \%$ & $\mathrm{n}=10$ & $30.0 \%$ & 0.070 & $\mathrm{n}=423$ & $69.7 \%$ & $\mathrm{n}=470$ & $79.6 \%$ & 0.001 \\
\hline Medially & $n=12$ & $33.0 \%$ & $n=14$ & $28.6 \%$ & 0.999 & $\mathrm{n}=420$ & $98.1 \%$ & $\mathrm{n}=466$ & $98.5 \%$ & 0.796 \\
\hline
\end{tabular}

Table IV. Comparison between the blind and people with normal vision with regard to the sensitivity and specificity of the diagnosis of cancers of intermediate dimensions at most (isolated cancer of small dimensions or cancer of intermediate dimensions).

\begin{tabular}{|c|c|c|c|c|c|c|c|c|c|c|}
\hline \multirow{2}{*}{$\begin{array}{l}\text { Imitation type } \\
\text { and location } \\
\text { Intermediate cancer } \\
\text { at most }\end{array}$} & \multicolumn{4}{|c|}{ Sensitivity } & \multirow[t]{2}{*}{$p$} & \multicolumn{4}{|c|}{ Specificity } & \multirow[t]{2}{*}{$p$} \\
\hline & & & & & & & & & & \\
\hline Total & $\mathrm{n}=66$ & $65.1 \%$ & $n=74$ & $50.0 \%$ & 0.088 & $n=798$ & $87.0 \%$ & $\mathrm{n}=886$ & $91.8 \%$ & 0.001 \\
\hline Peripherally & $\mathrm{n}=51$ & $74.5 \%$ & $n=56$ & $58.9 \%$ & 0.104 & $\mathrm{n}=381$ & $74.5 \%$ & $n=424$ & $84.4 \%$ & 0.001 \\
\hline Medially & $n=15$ & $33.3 \%$ & $n=12$ & $22.2 \%$ & 0.697 & $n=417$ & $98.3 \%$ & $n=462$ & $98.5 \%$ & 0.999 \\
\hline
\end{tabular}

Table V. Comparison between the blind and people with normal vision with regard to the sensitivity and specificity of the diagnosis of cancer (isolated cancer of small dimensions or cancer of intermediate dimensions at least)

\begin{tabular}{|c|c|c|c|c|c|c|c|c|c|c|}
\hline \multirow{2}{*}{$\begin{array}{l}\text { Imitation type } \\
\text { and location } \\
\text { Any cancer }\end{array}$} & \multicolumn{4}{|c|}{ Sensitivity } & \multirow[t]{2}{*}{$p$} & \multicolumn{4}{|c|}{ Specificity } & \multirow[t]{2}{*}{$p$} \\
\hline & & & & & & & & & & \\
\hline Total & $\mathrm{n}=84$ & $60.7 \%$ & $\mathrm{n}=94$ & $47.9 \%$ & 0.099 & $n=780$ & $87.7 \%$ & $\mathrm{n}=866$ & $92.5 \%$ & 0.001 \\
\hline Peripherally & $\mathrm{n}=69$ & $66.7 \%$ & $n=76$ & $54.0 \%$ & 0.130 & $n=363$ & $75.5 \%$ & $n=404$ & $85.6 \%$ & 0.001 \\
\hline Medially & $\mathrm{n}=15$ & $33.3 \%$ & $\mathrm{n}=18$ & $22.2 \%$ & 0.697 & $\mathrm{n}=417$ & $98.3 \%$ & $\mathrm{n}=462$ & $98.5 \%$ & 0.999 \\
\hline
\end{tabular}

(33.3 vs 22.2\%), however, it was not of statistical significance $(\mathrm{p}<0.697)$.

The specificity of detections was substantially higher in the group of people with normal vision compared to the blind, amounting to 93.7 and $89.6 \%$, respectively $(p<0.0004$; Tab. I). Specificity was also higher in the group of people with normal vision (control group) with regard to the medial and peripheral parts of breast - Tab. II.

The higher statistically significant sensitivity of examinations in the group of the blind and the higher statistically significant specificity of examinations in the group of people with normal vision is an interesting finding. This should be further analysed with regard to the causes of such phenomenon and its possible implications in practice.

Additionally, the precision of detection was determined in both groups by checking the sensitivity and specificity of the detection of cancers of small, intermediate and large dimensions and lesions other than cancers.

It was determined that the sensitivity of detection was always higher in the study group:

- 52.4 vs 29.2 ( $p$ < 0.138) for small cancers (Tab. III);

- 65.1 vs $50.0 \%$ for cancers of intermediate dimensions at most ( $\mathrm{p}<0.088$; Tab. IV);

- 60.7 vs $47.9 \%$ for all types of cancers $(p<0.099 ;$ Tab.V $\mathrm{Vand} \mathrm{VI})$; 
Table VI. Comparison between the blind and people with normal vision with regard to the sensitivity and specificity of the diagnosis of lesions other than cancer (cyst and fibroadenoma)

\begin{tabular}{|c|c|c|c|c|c|c|c|c|c|c|}
\hline \multirow{2}{*}{$\begin{array}{l}\text { Imitation type } \\
\text { and location } \\
\text { Other lesions } \\
\end{array}$} & \multicolumn{4}{|c|}{ Sensitivity } & \multirow[t]{2}{*}{$p$} & \multicolumn{4}{|c|}{ Specificity } & \multirow[t]{2}{*}{$p$} \\
\hline & & & & & & & & & & \\
\hline Total & $n=24$ & $70.8 \%$ & $n=26$ & $46.2 \%$ & 0.093 & $\mathrm{n}=840$ & $84.5 \%$ & $n=934$ & $89.5 \%$ & 0.002 \\
\hline Peripherally & $n=24$ & $70.8 \%$ & $n=26$ & $46.2 \%$ & 0.093 & $\mathrm{n}=408$ & $71.1 \%$ & $\mathrm{n}=454$ & $80.8 \%$ & 0.001 \\
\hline Medially & & & & & & $\mathrm{n}=432$ & $97.2 \%$ & $\mathrm{n}=480$ & $97.7 \%$ & 0.677 \\
\hline
\end{tabular}

-70.8 vs $46.2 \%$ for lesions other than cancer $(p<0.93$; Tab. VI)

Specificity was substantially higher in the control group for the examination of breasts and their peripheral parts while the specificity for the assessment of peripheral parts was similar for both groups and the differences were not statistically significant.

\section{Conclusions}

1. In line with the assumptions of this paper, the substantially higher sensitivity of the blind was determined in the detection of pathological lesions of the breasts. A substantial difference with regard to the specificity (to the disadvantage of the blind) reached a value of $4.1 \%$ for all assessments (the difference in specificity for all measures: 93.7\%, 89.6\%, Tab. II). Besides being statistically significant, it should be verified by a group of patients. Only verification at the bedside of a patient (accompanied by the results of histopathological examinations) may be helpful in the assessment of its clinical significance.

2. The results of the accuracy of the assessments made by blind physical therapists allowed for the initiation of the successive stage of the experiment - in a group of 120 patients.

3. The project, consisting of the use of the sensory abilities of the blind for the purpose of screening, deserves to be studied in a larger group of patients. The experiences in developing countries initially showed the value of this method in the diagnostic screening of the population.

Financial disclosure: The project referred to as Breast-POL is co-financed by the National Centre for Research and Development within the Social Innovations Programme

\section{Conflict of interest: none declared}

\section{Lidia Rakow, MS}

Fundacja Centrum Innowacji i Rozwoju, Poznań, Poland Department of Health Promotion and Postgraduate Education of the National Institute of Public Health

- National Institute of Hygiene, Warszawa, Poland

Chocimska 24

00-791 Warszawa, Poland

e-mail: I.rakow@fundacjacentrum.pl, Irakow@pzh.gov.pl

Received: 6 Sept 2016

Accepted: 3 Feb 2017

\section{References}

1. Adami H-O, Hunter D, Trichopoulos D (eds.). Textbook of cancer epidemiology. Oxford: Oxford University Press, 2008.

2. Didkowska J, Wojciechowska U. Nowotwory złośliwe w Polsce w 2013 r. Warszawa: Centrum Onkologii im. M. Skłodowskiej-Curie, Krajowy Rejestr Nowotworów, 2015

3. Harvey BJ, Miller AB, Baines $C J$ et al. Effect of breast self-examination techniques on the risk of death from breast cancer. CMAJ 1997; 157: 1205-1212.

4. McCready T, Littlewood D, Jenkinson J. Breast self-examination and breast awareness: a literature review. J Clinical Nurs 2005; 14: 570-578.

5. Miller $A B$, Baines $C J$. The role of clinical breast examination and breast self-examination. Prev Med 2011; 53: 118-120.

6. Nowicki A, Olszewska A, Humańska M. Wykrywanie raka piersi poprzez samobadanie. Badanie retrospektywne u kobiet po operacji. Ginekol Pol 2007; 78: 293-298.

7. Seidman H, Gelb SK, Silverberg E. Survival experience in the breast cancer demonstration project. CA Cancer J Clin 1987; 37: 258-290.

8. Weiss NS. Breast cancer mortality in relation to clinical breast examination and breast self-examination. Breast Journal 2003; 9 Suppl 2: S86-S89.

9. Wronkowski Z (ed.). Kontroluj swoje piersi. Warszawa: PZWL, 1999.

10. Hoffmann F.Medical tactile examiners (MTEs) improve eearly breast cancer detection [...], (http://www.rudermanfoundation.org/wp-content/ uploads/2014/12/Discovering-Hands-Expos\%C3\%A9.pdf).

11. Cruz GKP, de Franca ISX, de Oliveira CB et al. Retirando as vendas: conhecimento de mulheras cegas sobre cancer de mama. J Res Fund Care Online 2015; 7: 2486-2493.

12. De Franca ISX, de Sousa FS, Silva AF et al. Health education for early detection of breast cancer in blind women. Rev Rene 2015; 16: 890-899.

13. Haagensen C. Diseases of the breast. Philadelphia:W.B. Saunders, 1971.

14. Striem-Amit E. Neuroplasticity in the blind and sensory substitution for vision. PhD thesis. Hebrew University, 2013.

15. Konorski J. Integracyjna działalność mózgu. Warszawa: PWN, 1969.

16. Majewski T. Psychologia niewidomych i niedowidzących. Warszawa: PWN, 1985; s. 33-87.

17. Murray MM, Wallace MT (eds.). The neural bases of multisensory processes. Boca Raton (Florida): CRC Press, 2012.

18. Zemtsova MI, Sokolianski IA (eds.). Osobiennosti vosprijatija u slepykh i kompensatsija otsutsvuiuschego zrenija. Moskva: Izvestija Akad. Pedagogicheskich Nauk, 1957.

19. Żernicki B. Visual discrimination learning in binoculary deprived cats: 20 years of studies in the Nencki Institute. Brain Res Rev 1991; 16: 1-13.

20. Żernicki B. Plastyczność mózgu — uwagi wstępne. In: Kossut M. (ed.). Mechanizmy plastyczności mózgu. Warszawa: PWN; 1994, s. 9-14.

21. Heller MA, Schiff W (eds.). The psychology of touch. New York, London: Psychology Press, Taylor \& Francis Group, 2009.

22. Sathian K, Stilla R. Cross-model plasticity of tactile perception in blindness. Restor Neurol Neurosci 2010; 28: 271-281.

23. Wan $C Y$, Wood AG. Reutens DC et al. Congenital blindness leads to enhanced vibrotactile perception. Neuropsychologia 2009; 48: 631-635.

24. Heidary F, Gharebaghi R, Heidary R. Palpation by blind examiners: A novel approach for glaucoma screening. Clin Ophtalmol 2010; 4: 671-672.

25. Van Belle G, Fisher LD, Heagerthy PJ et al. Biostatistics: A methodology for the health sciences. New Jersey: John Wiley \& Sons, 2004.

26. SAS/STAT 12.1 User's Guide. Cary, NC: SAS Institute Inc, 2012. 